\title{
TESL Canada: National Contributions to ESL Professionalism in Canada
}

\section{Catherine Eddy and Carol May}

\begin{abstract}
Professionalism is a goal for all English as a Second Language teachers, and yet it is a concept whose precise definition remains elusive. Since its inception, TESL Canada has been engaged in activities promoting professionalism, most notably in the areas of advocacy, professional development, and national standards. This article chronicles TESL Canada's activities to support increasing professionalism among ESL educators across the nation.
\end{abstract}

Alors que le professionnalisme constitue un des objectifs de tout enseignant en ALS, une définition précise de ce concept demeure insaisissable. Depuis sa création, TESL Canada a toujours oeuvré dans des activités qui font la promotion du professionnalisme, notamment en ce qui concerne la défense des intérêts de la discipline, le développement professionnel et l'établissement de normes nationales. Cet article fait le bilan des activités entreprises par TESL Canada pour favoriser l'accroissement du professionnalisme chez les enseignants en ALS de par le pays.

\section{Introduction}

A defining characteristic of a profession is the "existence of an institution that serves as the voice and agent of the profession" (Mokgalane, 2004). TESL Canada has served as that voice and agent of ESL educators for the past 25 years. This article documents the origins and structure of TESL Canada and its major endeavors in promoting professionalism among its membership, including advocacy, professional development, and national standards.

\section{Origins}

Talk of creating a Canadian national ESL organization began in the late 1960s, but was only actuated when a first meeting was held at the 1977 TESL Ontario Conference (TESL Canada Newsletter, 1(1), 1979, p. 1). The provincial/territorial representatives struck a Steering Committee to write a draft constitution, which was passed in 1978, and the TESL Canada Federation became officially incorporated in 1984 (TESL Canada Board of Directors Handbook, 2003, By-Laws).

TESL Canada was identified as "a federation of those concerned with the teaching of English as a Second Language/Dialect in Canada" (TESL Canada 
Newsletter, 1(2), 1981, p. 2). The objectives, as set out in its constitution and by-laws, were:

- To promote communication among the various jurisdictions;

- To encourage and support the promotion of policies related to TESL/D;

- To coordinate the dissemination of information in fields related to TESL/D. (pp. 2-3)

These objectives were retained until the mid 1990s, when they were reviewed. This review was part of a larger context to create a Mission Statement for the Federation, and to then ensure that the objectives were consistent with this statement.

After much discussion, the Mission Statement and Objectives were approved by the TESL Canada Board of Directors in September, 1995.

The Mission Statement is as follows:

TESL Canada is a national organization dedicated to advancing communication and coordinating awareness of issues for those concerned with English as a second language and English skills development. The organization promotes advocacy for ESL learners, unifies teachers and learners by providing a forum and network capabilities, supports the sharing of knowledge and experiences across Canada, and represents diverse needs and interests in TESL nationally and internationally. (TESL Canada Bulletin, December, 1995, p. 8)

The Objectives of TESL Canada are:

- To promote communication among the various jurisdictions across Canada in which language training takes place;

- To encourage and promote TESL and English language skills development policies compatible with the Mission Statement of the Federation;

- To encourage the establishment of associations in jurisdictions where none exist;

- To support the inclusion in the Federation of those involved with language and settlement issues;

- To advocate on behalf of those who require assistance regarding language and settlement issues;

- To foster scholarship, research, and the regular exchange of ideas amongst those involved in additional language teaching and learning;

- To foster organizational, technological, and pedagogical support for language training programs;

- To work cooperatively with like-minded organizations; and

- To represent national interests and concerns in the international arena. (TESL Canada Bulletin, December, 1995, p. 8)

It was believed that this Mission Statement accurately reflected the directions that the Federation had taken since the early 1980s and is continuing to 
take. It was also believed that these objectives captured the essence of the original objectives of the organization.

\section{Structure}

The TESL Canada Federation functions under the leadership of a Board of

Directors (TESL Canada Board of Directors Handbook, 2003, Directory). This Board consists of an Executive Committee, which includes as senior officers President, Past-President, Vice-President, Treasurer, and Secretary. The remaining directors consist of one representative member from each of the nine provincial ESL organizations and the Yukon Territory and a maximum of five members-at-large. The provincial/territorial directors are selected by their ESL organizations in Newfoundland/Labrador, New Brunswick, Nova Scotia, Prince Edward Island, Ontario, Manitoba, Saskatchewan, Alberta, British Columbia, and the Yukon Territory to sit on the Board. ${ }^{1}$ The Executive Committee and five members-at-large are elected by the TESL Canada membership at its annual general meeting. The Board of Directors is supported by an Executive Director, who reports directly to the senior officers.

Individuals who are members of their provincial/territorial ESL organization are automatically members of the TESL Canada Federation. This duality of membership enables individuals to become aware of, and involved in, both the provincial and national TESL arenas.

\section{Advocacy}

Advocacy was one of the initial pillars of the Federation and remains one of its foremost building blocks.

\section{The Six Principles}

In the early 1980s TESL Canada was involved in creating a position paper on "Six Principles Towards a National Policy" on the provision of ESL training to adults (TESL Canada Newsletter, 2(1), 1982, pp. 2-12). These principles are identified below as they reflect issues and concerns that still exist today.

- The Principle of Accessibility to ESL for all newcomers,

- The principles of flexibility and sufficiency,

- The principle of national, provincial and local coordination,

- The principle of support for community agencies,

- The principle of functional Canadian orientation and citizenship in ESL material, and

- Recognition of the key roles of the ESL professional and the ESL profession.

These principles included Aboriginal peoples and Francophone communities as well as recent arrivals of all ages, learning abilities, and styles. 
The Honorable Lloyd Axworthy (at that time Minister of Employment and Immigration) was invited to the TESL Canada Conference in Edmonton in November 1982 to respond to the issues raised in the TESL Canada position paper. He stated:

If we don't provide proper immigration settlement for those we bring, there will be a reaction, a backlash, and therefore part of our job must be to enhance the ability of those who come to Canada to become part of the society and community - without forming a kind of hostility and antagonism that can grow. (Elson, 1983, p. 2)

\section{LINC and the National Working Group}

By 1992 the federal government had created a Language Training Policy and had reallocated language training dollars to the creation of this Language Instruction to Newcomers to Canada (LINC) program. The TESL Canadian leadership of the day recognized, however, that the initiatives of Employment and Immigration Canada-EIC (now Canadian Immigration CanadaCIC) fell far short of a commitment to a national policy on language training for immigrants and refugees, and renewed its advocacy commitment. Student eligibility, suitability of the A-LINC assessment tool, placement of students, program issues (including content, standards, quality, accountability, administration, instructional focus, duration of courses, exit standards), and "child minding" continued to be problematic in every province (TESL Canada Bulletin, December, 1992, p. 1). The federal government's approach was to "develop provincially/locally based solutions," but TESL Canada leaders perceived that inconsistent application of the federal language training policy could be inequitable and contradictory to the original intent of the new policy. TESL Canada's involvement and advocacy action resulted in changes to the LINC eligibility and funding clauses. TESL Canada's commitment to advocacy work was then continued with its involvement with the National Working Group (NWG) on Language Benchmarks (TESL Canada Bulletin, Spring 1998, p. 8). In contemplating the work being initiated to address language benchmarks for learners, questions and concerns were simultaneously being raised about the need for national standards for teachers of these adult learners (see section on National Standards below).

The National Working Group was mandated:

- To recommend to EIC a process for developing benchmarks;

- To recommend to EIC the terms of reference to be used in a Request for Proposals to solicit proposals for developing the benchmarks;

- To identify consultants who should be asked to respond to the Request for Proposals;

- To review all such proposals and prepare a short list for EIC; 
- To review, periodically, the work of the selected contractor(s) to ensure that it is consistent with EIC language training policy and terms of the contract and suggest modifications to the process and the product, as required;

- To recommend to EIC a process for the introduction and operation of the benchmarks;

- To monitor the implementation of the benchmarks during the first year and recommend modifications and adjustments if needed, in light of EIC's language training policy; and

- To assist in the dissemination of progress reports and draft products to all stakeholder groups. (TESL Canada Bulletin, April, 1993, p. 1)

TESL Canada continued to work with Citizenship and Immigration Canada (CIC) staff on the development and refinement of the LINC Benchmarks and Assessment projects. The national coordinating responsibilities for these projects had been undertaken as part of CIC's mandate, but by late 1996, the National Steering Committee had been charged with finding a new home for the project.

TESL Canada was a contender to assume these national coordinating responsibilities. It had been part of the Benchmarks project since its inception and was in a position to provide responses and responsible national coordination of the further development and application of the Benchmarks (McMichael, 1997).

The final decision, however, was to create a Centre for Canadian Language Benchmarks (CCLB), a national agency that would assess, administer, and develop the national proficiency level standards that TESL Canadians had been instrumental in developing. By March 1998, the CCLB was a reality (TESL Canada Bulletin, Spring, 1998).

\section{Centre for Canadian Language Benchmarks (CCLB)}

The CCLB is a national, not-for-profit organization, primarily serving the adult English as a Second Language (ESL) community in Canada including learners, teachers, program administrators; and materials, curriculum, and test developers (Centre for Canadian Language Benchmarks, 2004, About $U$ s). Its mandate is to develop, promote and conduct research in support of the Canadian Language Benchmarks, and to encourage the alignment of curriculum and program structure with the Canadian Language Benchmarks (Centre for Canadian Language Benchmarks, 2004, Our Mandate).

The Canadian Language Benchmarks are a descriptive scale of communicative proficiency in ESL, expressed as benchmarks or reference points. They provide a framework of reference for learning, teaching, programming, and assessing adult ESL learners in Canada, a national standard for planning second-language curricula for a variety of contexts, and a common yardstick 
for assessing the outcomes across the country (Centre for Canadian Language Benchmarks, 2004, Benchmarks).

\section{Professional Development}

Professional development of the members of any organization/federation can take many forms. TESL Canada has chosen to focus on three major areas: national conferences, learners' conferences, and professional publications.

\section{National Conferences}

Professionalism among its members is organizationally enhanced through conferences, giving opportunities to come together, to share, and to learn. Professional conferences afford opportunities for ESL teachers to acquire knowledge, to increase their competence, to build on their openness to continuing change related to methodology and practice, and to reinforce good judgment and ethical behavior. All of the above are viewed as attributes of a professional.

TESL Canada held its first National Conference in Montreal, Quebec, in spring 1979 (TESL Canada Newsletter, 1(1), 1979) and has continued to provide these professional development opportunities approximately every 18 months throughout the ensuing years. TESL Canada believes in co-hosting provincial/local conferences, so adopted a national conference time period to support this. The list of conference locations shown in Table 1 indicates TESL Canada's commitment to moving the conference sites across the country to enable participants from all regions to participate in these professional development opportunities. The caliber of plenary speakers at the conferences has remained consistently high, with plenary speakers from Canada, the United States, and elsewhere speaking at each conference. TESL Canada conferences have been held as shown in Table 1 (TESL Canada Board of Directors Handbook, 2003, Conferences).

The TESL Canada Conferences offer quality workshops, with normally over 100 presenters from across Canada as well as from international locations. In more recent years, the concept of strands has been incorporated into the conference program (Eddy \& Helmer, 2003). Strands are focus areas that provide delegates with opportunities to pursue a theme of interest to them and to be able to explore this theme from a variety of points of view. A major part of the conferences is a full day of symposia, in-depth half-day, or full-day workshops that address hot issues of concern to ESL professionals. The involvement of publishers' representatives enables delegates continually to become aware of the latest materials and programs that might enhance their teaching and learning.

It is generally believed by conference delegates that one of the most important functions of a conference is to facilitate networking. Networking can be done formally or informally, but it is the discussions between and 
Table 1

TESL Canada Conferences

\begin{tabular}{|c|c|c|c|c|}
\hline No. & Year & Date & Location & Title \\
\hline 1. & 1979 & May 23-27 & Montreal, QC & $\begin{array}{l}\text { TESL Canada's First National } \\
\text { Conference }\end{array}$ \\
\hline 2. & 1981 & Mar 12-14 & $\mathrm{BC}$ & Untitled \\
\hline 3. & 1982 & Nov 11-13 & Alberta & Untitled \\
\hline 4. & 1984 & Feb $9-11$ & Winnipeg, MB & $\begin{array}{l}\text { Language: The Key to Canadian } \\
\text { Living }\end{array}$ \\
\hline 5. & 1985 & Nov 21-24 & Toronto, ON & Untitled \\
\hline 6. & 1987 & Mar 12-14 & Vancouver, BC & Pacific Perspectives \\
\hline 7. & 1988 & Jun 15-18 & Quebec City, QC & Untitled \\
\hline 8. & 1989 & Nov 2-4 & Calgary, AB & $\begin{array}{l}\text { Language Development in the } \\
\text { CanadianCommunity }\end{array}$ \\
\hline 9. & 1991 & May 2-4 & Saskatoon, SK & Part of the Picture! \\
\hline 10. & 1993 & May $13-15$ & Halifax, NS & Tradition and Change \\
\hline 11. & 1994 & Nov $24-26$ & Toronto, ON & Networking for the '90s \\
\hline 12. & 1996 & May 10-11 & Winnipeg, MB & Linking the Nation \\
\hline 13. & 1997 & Nov $7-9$ & Victoria, BC & World Skills: Language and Living \\
\hline 14. & 1999 & May $13-15$ & Banff, AB & Meeting the Millennium \\
\hline 15. & 2000 & Sep 23-30 & Halifax, NS & Changing Faces: Facing Change \\
\hline 16. & 2002 & May $16-18$ & Regina, SK & Catch the Dream \\
\hline 17. & 2003 & Nov 13-15 & Vancouver, BC & $\begin{array}{l}\text { Connecting Communities: } \\
\text { Inspirations and Aspirations }\end{array}$ \\
\hline
\end{tabular}

among educators on topics of shared interest and concern that often provide the most lasting memories. Experienced ESL educators join with those newer to the profession in a variety of conference venues and on a multitude of levels, which may include workshops, meals, entertainment evenings, poster sessions, and the electronic village.

\section{Learners' Conferences}

TESL Canada is the only national organization to invite its learners to participate in its proceedings. This invitation was initiated as part of TESL Canada's 1991 national campaign to raise public awareness of:

- ESL issues, including the right of ESL learners to participate fully in Canadian society, and

- the need to improve ESL programs and services to meet the needs of adult and child ESL learners (TESL Canada Bulletin, December, 1991, p. $1)$. 
Public awareness about the importance of ESL instruction in Canada was brought to the forefront in the late 1980s and early 1990s. One result of this was to ask learners themselves to participate in the 1991 TESL Canada/ SCENES conference to articulate their needs and concerns. TESL Canada embraced the notion of listening to learners, the receivers of so much professional time and attention, and institutionalized the concept of having a Learners' Conference as part of its regular conference proceedings (TESL Canada Board of Directors Handbook, 2003, Projects, Awards, Activities).

The most extensive statement of purposes for the learners' conferences is included in the 1993 conference report (Weidenhammer, 2002), which lists four goals:

- To provide a forum for the independent expression of ESL learners' concerns;

- To promote learners' concerns using the conference event as a means for involving government representatives and informing the public through the media;

- To promote meaningful, significant, extensive language experiences for learners through involvement in the processes of conference planning, participation, and reporting; and

- To achieve a national network of ESL learners through the meeting of concerned learner delegates.

Learners' conferences have taken place as shown in Table 2 (TESL Canada Conference Handbook, 2002, Learners Conferences).

Focuses for the initial learners' conferences varied, and reflected evolving federal and provincial government initiatives in adult ESL education. Recurring thematic structures over the years have included styles of learning, accessing information about ESL and other training programs and opportunities, employment issues, surviving, settling and adapting to a new culture, family communication, literacy and violence, culture shock, and the Canadian Language Benchmarks.

Later learners' conferences continued to focus on the Canadian Language Benchmarks and Advocacy (Weidenhammer, 2002), which simultaneously moved closer to other federal government initiatives. This was realized most recently in the 2003 learners' conference, which focused on barriers to integration (McMichael, 2004). During this conference, four areas were explored, including:

- Building inclusion by bringing citizens and newcomers into the settlement process and keeping them there;

- Building respect by ensuring that settlement services are culturally sensitive and accountable to the communities being served;

- Building capacity by strengthening intra- and intercultural community relationships; and 
- Building resources by developing and sharing information resources among all community members.

These topic areas were a direct result of previous discussions both within TESL Canada conferences and TESL Canada's participation in the federal government's Voluntary Sector Initiatives (VSI) project. Conference participants in 2003 were charged with developing proposals for pilot projects that could be implemented in 2004 and findings that could inform discussion at the 2005 learners' conference and would encourage the local involvement of immigrants and refugees in the integration process.

Two proposals emerged, one focusing on the provision of enhanced language training and credential matching services to immigrant professionals, and the other on profiling the service needs of typical immigrant families over a six months. Potential findings could be used to influence the decisions of federal government agencies and settlement agency services respectively in the years ahead.

\section{TESL Canadian Educational Foundation}

Discussions about creating the TESL Canadian Educational Foundation (TCEF) began in the early 1990s. The idea was to have a mechanism in order to garner and dispense monies for projects that were consistent with, and promoted, the Federation's mandate and purposes. The TCEF was registered as a charity effective January 1, 1992 (TESL Canada Board of Directors Handbook, 2003, Projects, Awards, Activities).

Table 2

Learners' Conferences

\begin{tabular}{|c|c|c|c|c|}
\hline No. & Year & Date & Location & Title \\
\hline 1. & 1991 & May 2-4 & Saskatoon, SK & $\begin{array}{l}\text { Getting the Picture; Helping Change } \\
\text { the Picture }\end{array}$ \\
\hline 2. & 1992 & Mar 2-4 & Vancouver, BC & Untitled \\
\hline 3. & 1993 & May $13-15$ & Halifax, NS & Untitled \\
\hline 4. & 1994 & Nov $24-26$ & Toronto, ON & $\begin{array}{l}\text { Implementing the Activities of the } \\
\text { National Working Group }\end{array}$ \\
\hline 5. & 1996 & May $10-11$ & Winnipeg, MB & Families and ESL \\
\hline 6. & 1997 & Nov $7-9$ & Victoria, BC & Taking Charge of Our Learning \\
\hline 7. & 1999 & May 13 & Banff, AB & $\begin{array}{l}\text { Meeting the Millennium-A } \\
\text { Learners' Video Conference }\end{array}$ \\
\hline 8. & 2000 & Sep $28-30$ & Halifax, NS & Beyond the Classroom \\
\hline 9. & 2002 & May $16-18$ & Regina, SK & Full Circle \\
\hline 10. & 2003 & Nov $13-15$ & Vancouver, BC & $\begin{array}{l}\text { Connecting Communities- } \\
\text { Inspirations and Aspirations }\end{array}$ \\
\hline
\end{tabular}


The purposes of the Foundation are:

- To fund, facilitate, promote, and carry on activities, research and teaching which will advance education and in particular, without restricting the foregoing, will promote and facilitate the learning of English as an additional language and an understanding of the impact of the learner's cultural environment on the ability to learn additional languages;

- To receive bequests, trusts, funds and property, and to hold, invest, administer and distribute funds and property for the purposes of the society as presently set out and for such other organizations as are "qualified donees" under the provisions of the Income Tax Act and for such other purposes and activities which are authorized for registered charities under the provisions of the Income Tax Act. The directors in their sole and absolute discretion may refuse to accept any bequests, trusts, funds or property; and

- To do all such things as are incidental and ancillary to the attainment of the purposes and the exercise of the powers of the Society.

The establishment of the Foundation meant that monies could be sought from a variety of sources to support activities relating to its purposes, which are compatible with the Federation's objectives. A major source of commitment for the Foundation's monies to date has been to support the TESL Canada Learners' Conferences as part of each national TESL Canada Conference (see section on Learners' Conferences above).

\section{Publications}

Another endeavor of a profession organization is to publish a professional journal for its members. The TESL Canada Journal was established in 1984 as a fully refereed journal for practicing teachers, teacher educators, graduate students, and researchers (TESL Canada Board of Directors Handbook, 2003, Publications).

\section{The TESL Canada Journal}

The TESL Canada Journal invites the submission of unpublished manuscripts concerning diverse aspects of the teaching and learning of ESL/EFL/SESD, including syllabus and curriculum design, testing and evaluation, psycholinguistics, applied linguistics, teacher training, methodology, and computerassisted language learning (TESL Canada Journal, 21(2), 2004, Editorial Policy). The TESL Canada Journal is recognized internationally for its quality of content, and much credit must go to the volunteer editors who have worked diligently to uphold high editorial and publication standards. It has a circulation of over 5,000 .

To serve the broad range of Canadian ESL/EFL/SESD educators, TESL Canada has undertaken: 
- To ensure that all journal abstracts and editorials at least are available in both Canada's official languages, and

- To ensure that the journal articles are indexed on the TESL Canada Web site for generic access (www.tesl.ca).

Special issues. In addition to the regularly published journals (twice yearly), TESL Canada supports the publication of special issues, generally on specific topic areas of national interest. Three special issues have been published:

- Special Issue 1, "Both Sides of the Desk: Roles and Responsibilities in ESL/EFL Teaching and Learning" (Lightbown \& Firth, 1986);

- Special Issue 2, "An Annotated Bibliography of Canadian ESL Materials" (Cumming, 1990); and

- Special Issue 3, "An Annotated Bibliography of Teaching and Learning Materials for Adult Newcomers to Canada" (Cumming, Burnaby, Weinrib, Holunga, Lopes, \& Paulauskas, 1993).

\section{The TESL Canada Bulletin}

The TESL Canada Bulletin (initially entitled the TESL Canada Newsletter) has been in existence since the early 1980s. The Bulletin has a biannual circulation of over 5,000 TESL Canada members and over 200 libraries worldwide. The Bulletin is a summary of news and views from the provincial members and international contacts; provincial, national, and international conference information; current events; and a variety of ESL-related activities. In 2001 the Bulletin became available online for the first time, and members are now able to view it on the TESL Canada Web site at www.tesl.ca.

\section{TESL Canada Life Member Awards}

Part of the Federation's professional activities includes honoring those who have provided leadership and made exemplary contributions to TESL in Canada throughout their professional careers (TESL Canada Board of Directors Handbook, 2003, Projects / Awards/Activities). To recognize such individuals, in 1998, TESL Canada created a Life Member Award, the purpose of which is to honor our "living national treasures." The introduction of this award included the fact that TESL Canada was

looking for those outstanding individuals on whom we count for wise counsel and unfailing support, those who have shown leadership in both the workplace and the community in such areas of our involvement as academic, vocational, sociocultural and linguistic instruction, cross-cultural counseling, labour market access training, citizenship training and multicultural liaison". Nominees must have provided outstanding service over a period of not less than 20 years. (TESL Canada Board of Directors Handbook, 2003, Projects/Awards/Activities). 
To date, life member awards have been given to Joan Acosta, $\mathrm{BC}$; Eleanor Rogers, Ontario; Mary Ashworth, BC; Virginia Sauvé, Alberta; Virginia Christopher, BC; Elizabeth Taborek, Ontario; Elizabeth Coelho, Ontario; and Patricia Wakefield, BC. These awards of merit, given to outstanding people, typify TESL Canada's commitment to excellence in TESL teaching and research. They also provide younger TESL Canadians with examples of leadership and service. Information about the recipients can be found on the TESL Canada Web site (www.tesl.ca).

\section{National Standards}

The continuing questions about the need for national standards, dating from the early 1990s, gave rise to a TESL Canada Certification Special Interest Group in the summer of 1996 (Begin, 1996). The purpose of this group was to work toward the creation of a national certification document that would provide national standards for professionals and institutions in the adult ESL field. Extensive work, consultations, preliminary presentations, discussions, reviews, and refinements led to the completion of this document.

The development of the National Recognition Standards (NRS) was driven by a commitment to ensure the accessibility, reliability, and sufficiency of language training in Canada. The primary goal has been to promote excellence in ESL education by developing and promoting standards that are recognized both nationally and internationally. Two sets of standards have been created: the National Professional Certification Standards and the $\mathrm{Na}$ tional Teacher-Training Recognition Certification (see www.tesl.ca).

\section{National Professional Certification Standards}

The purpose of the National Professional Certification Standards (TESL Canada, 2004, March 21a) is to promote excellence in the teaching and learning of English as a Second Language across Canada by promoting professional certification standards that are recognized in all provinces.

The Standards benefit educators by helping ensure that:

- TESL training and ESL teaching experience are recognized as main professional measures of Canadian ESL educators;

- Teaching credentials are recognized not only from province to province but, by virtue of their national status, from country to country;

- Credentials are recognized by international students when they compare faculty at postsecondary schools and language institutes across Canada before their arrival in Canada;

- Qualifications are valued appropriately by government and non-government funders when educators request financial support for awards, scholarships, and projects.

Developed through participation and feedback across the ESL field, these standards address the professional context of Canadian ESL educators. TESL 
Canada recognizes that Canadian ESL delivery varies widely in structure and specifics and continues to develop these standards through feedback and the appeal process.

TESL Canada National Professional Certification Standards, which identify four levels of certification, provide a national focus on standards for all ESL educators and encourage high levels of participation in an accreditation system that recognizes and values the diversity of approach to ESL instruction in its many settings. Since their implementation in May 2002, the TESL Canada National Professional Certification Standards are becoming the authoritative base for evaluation and comparison of ESL teacher training in Canada (TESL Canada, 2004, March 21b).

The TESL Canada National Professional Certification Standards represent a teacher-driven initiative to create basic, minimum national standards. Some provinces currently have professional certification systems in place, and the TESL Canada professional certificate is not intended to replace provincial professional certificates where they exist. Professionals can choose to hold both TESL Canada and provincial organization certificates.

\section{National Teacher Training Program Recognition}

In order for ESL teachers to receive TESL Canada National Professional Certification, TESL Canada believed it critical to recognize the teacher training programs from which these graduates come (TESL Canada, 2004, March $21 b)$.

It was acknowledged that there are many quality TESL training programs across Canada dedicated to preparing prospective English language instructors for the challenges of teaching in Canada and abroad. TESL Canada developed a recognition system for programs that meet the standards for TESL Canada Professional Certificate Level 1 (see tesl.ca). The goal is to ensure that instructors receive the best training to enable them to provide ESL learners with excellent instruction in a wide variety of settings.

The guidelines outline the requirements in the categories of facilities, resources, qualifications of personnel, institutional accreditation, program content, and assessment processes. A TESL Canada Teacher Training Program Review Committee examines applications and awards certificates of recognition.

To ensure the continuation of quality programming, recognized teacher training programs receive a certificate that must be renewed every three years. A list of the recognized programs in Canada can be found on the TESL Canada Web site at www.tesl.ca.

In May 2003, the TESL Canada Professional Certification Standards were adopted by the Canada Language Council-a new national association of public, private, and nongovernment organizations of English and French language programs (Christopher, 2003). This group combines the Council of 
Second Language Programs, Languages Canada, and Private English Language Schools Association to form an association of language programs for providers of adult ESL/FSL, in all contexts, based on national standards. TESL Canada, with its national TESL standards, has been the catalyst in the establishment of this more comprehensive national body. Canada will now be able to compete on an equal footing with Australia, New Zealand, the US, and the United Kingdom, as all these countries have such a national association that is recognized and assisted by their governments.

\section{Conclusion}

Throughout the past 25 years, TESL Canada has continued to make significant contributions to the professionalism of ESL teaching and learning in Canada. These contributions have been, and are, based on the three pillars of advocacy, professional development, and the development and implementation of national standards for both professional certification for teachers and a recognition process for teacher training programs.

Another area where TESL Canada is beginning to work is the establishment of a national Code of Conduct. As a national federation, TESL Canada has been slower to act in this arena because a number of its constituent members have already developed provincial codes of conduct. It is our belief, however, that a national code of ethics/conduct needs to be developed and articulated by TESL Canada. It is reassuring that a TESL Canada committee has been struck to address this question, and it is hoped that a National Code of Ethics will be available in the near future.

These TESL Canada activities have been possible because of the many thousands of hours of dedicated work and commitment by ESL professionals in the field, including schools, colleges, and universities. We owe each of them a debt of gratitude for their vision and for their unfailing efforts to turn these visions into realities.

\section{Note}

${ }^{1}$ The Quebec organization Societé pour la promotion de l'enseignement de l'anglais (langue seconde) au Québec (SPEAQ) had been a TESL Canada member until it withdrew its provincial member status in October 1991. Since that time, a SPEAQ member has been elected to sit on the TESL Canada Board of Directors as a member-at-large.

\section{Acknowledgments}

References for this article were taken from the TESL Canada Bulletins, National and Learners' Conference Reports, Journal Editorials, Presidential, Provincial, and Committee Reports. These documents are housed in the TESL Canada archives in Burnaby, BC. Special thanks are extended to all the TESL Canada Boards, Committees, Conference Committees, Journal Editors, and Special Interest Groups who volunteer their time and energy in supporting TESL Canada and thereby their profession. 


\section{The Authors}

Catherine Eddy is an ESL teacher and administrator in the Vancouver School Board, and a Past-President of TESL Canada.

Carol May is the TESL Canada Executive Director. She has been involved in ESL non-profit management for over 20 years.

\section{References}

Begin, S. (1996). TESL Canada certification and special interest group report. TESL Canada Bulletin, December.

Centre for Canadian Language Benchmarks. About us. Retrieved March 21, 2004, from www.language.ca

Christopher, V. (2003). Professional Certification Standards Committee report. TESL Canada Board Meeting Minutes, June. Burnaby, BC: TESL Canada Archives.

Cumming, A. (Ed.). (1990). An annotated bibliography of Canadian ESL materials. TESL Canada Special Issue 2.

Cumming, A., Burnaby, B., Weinrib, A., Holunga, S., Lopes, J., \& Paulauskas, S. (Eds.). (1993). An annotated bibliography of teaching and learning materials for adult newcomers to Canada. TESL Canada Special Issue 3.

Eddy, C., \& Helmer, S. (2003). TESL Canada Bulletin, Spring.

Elson, N. (1983, March). TESL Canada Newsletter, 1(3).

Lightbown, P., \& Firth, S. (Eds.). (1986). Both sides of the desk: Roles and responsibilities in ESL/EFL teaching and learning. TESL Canada Special Issue 1.

McMichael, W. (1997). TESL Canada Bulletin, Spring.

McMichael, W. (2004). Preliminary report on the 2003 TESL Canada Learners' Conference. Burnaby, BC: TESL Canada Archives.

Mokgalane, E. (2004). Let's talk teacher professionalism. SACE (South African Council for Educators). Retrieved July 10, 2004, from http://sace.org.za/Sace/

TESL Canada. Retrieved March 21a, 2004, from http:/ / tesl.ca/HTML/ApprovedTTInst04.html TESL Canada. Retrieved March 21b, 2004, from http://tesl.ca/HTML/national_standards.html TESL Canada Board of Directors Handbook. (2003). Burnaby, BC: TESL Canada Archives.

TESL Canada Bulletin. Burnaby, BC: TESL Canada Archives.

TESL Canada Conference Handbook. (2002). Burnaby, BC: TESL Canada Archives.

TESL Canada Journal. Burnaby, BC: TESL Canada Archives.

TESL Canada Newsletter. Burnaby, BC: TESL Canada Archives.

Weidenhammer, H. (2002). Learners' conferences. TESL Canada Conference Handbook. Burnaby, BC: TESL Canada Archives. 